http://kitaibelia.unideb.hu/

ISSN 2064-4507 (Online) • ISSN 1219-9672 (Print)

(C) Department of Botany, University of Debrecen, Hungary

23 (2): 141-150.; 2018

DOI: $10.17542 /$ kit.23.141

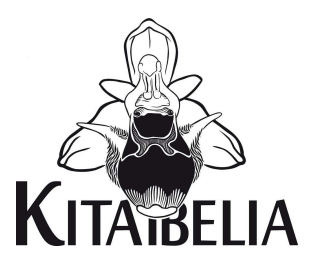

\title{
Sótűrő budavirágfajok terjedése a Dunántúl útjain
}

\author{
SCHMIDT Dávid*, HASZONITS Győző \& KoRDA Márton \\ Soproni Egyetem, Erdőmérnöki Kar, Növénytani és Természetvédelmi Intézet, \\ H-9400 Sopron, Bajcsy-Zsilinszky u. 4.; *schmidt.david@uni-sopron.hu
}

Spreading of native Spergularia species along roadsides of Transdanubia (NW Hungary)

Abstract - During the systematic floristic research along Transdanubian roads (NW Hungary) since 2013, two native halophyte Spergularia species has been found. Due to the well known spreading near motorways in Eastern-Central Europe, the appearance of Spergularia marina along roads in northwestern Hungary is not a surprise. Occurrences of the species were registered along fourteen main roads. Some of the stands are very rich where $S$. marina forms single-species lines along the asphalt edge. The spreading of Spergularia media along roads is yet much less intensive. Four stands were found near the motorways M1 and M7, main road 74, and the common section of the main road 86-87. Both species are native in the Hungarian plains, being specific elements of Pannonic alkali grassland associations, however, their secondary migration along road edges is promoted by road salting, intensive management of roads and increased vehicle traffic. In this paper, we specify secondary occurrences of the two Spergularia species, discuss their ecological and abiotic circumstances and publish corresponding distribution maps. Due to recognition problems in Spergularia, a corrected determination key was provided.

Keywords: motorway, road ecology, road network, salting, salt tolerant species

Összefoglalás - Az észak-dunántúli főközlekedési utak környezetének 2013-tól folytatott florisztikai feltárása során összesen 826 kilométer hosszú útszakaszt vizsgáltunk. Kimutattuk a hazánkból korábban csak természetközeli élőhelyekről ismert Spergularia marina és Spergularia media állományait. Nyugatról kelet felé helyenként futótűzszerü terjedést mutat a Spergularia marina, amely összesen 14 főközlekedési út padkájáról került kimutatásra. Számos lelőhelyén monodomináns növényzeti sávot képez. Kisebb intenzitású a Spergularia media terjedése, amelyet 4 főközlekedési út mellett regisztráltunk. Mindkét faj a hazai szikes társulások jellegzetes eleme, útmenti terjedésük hátterében azonban az utak intenzív sózása, valamint a belföldi és nemzetközi gyorsforgalmi úthálózat töretlen fejlesztése és a megnövekedett autóforgalom áll. Munkánkban a két faj másodlagos terjedését mutatjuk be, tárgyaljuk a terjedés hátterében húzódó abiotikus és ökológiai háttérviszonyokat. A nemzetség határozási nehézségeinek enyhítése érdekében kiegészített határozókulcsot teszünk közzé.

Kulcsszavak: autóút, sótűrő növények, sózás, útökológia

\section{Bevezetés}

A magasabb rendű autóutak hálózatát napjainkban előre tervezett és meghatározott építési és fenntartási szabályrendszer szerint múködtetik. A korábbi évtizedekhez mérten egyre nagyobb léptékű úthálózat-fejlesztés eredményeként nemzetközi úthálózati tengelyek, zárt ökológiai folyosók jöttek létre. Ennek a rendszernek az útpadkákon megjelenő vegetáció szempontjából az egyik legmeghatározóbb tényezője a téli jégmentesítésre alkalmazott sózás. Hazai autóutakon az 1960-as évektől alkalmaznak nátrium-kloridot a jég olvasztására, 
amelynek környezetre gyakorolt hatásait néhány évtizeddel később felismerték (KöLES 1994), más módszerekkel szembeni előnyös tulajdonságai miatt ugyanakkor a mai napig a leggyakrabban alkalmazott technológia. Különösen nagy mennyiségben a zárt rendszerben múködő magasabb rendű utakon (autópályák, autóutak) alkalmazzák, ahol a biztonságos közlekedési feltételek fenntartása a legfontosabb feladat.

Az első, útsózás hatására megjelenő sótűrő növényfaj a hazánkban szikes réteken állományképző Puccinellia distans volt (KÁRPÁTI 1954), amely ma már országszerte az útpadkák legáltalánosabban elterjedt növényének számít. Közutak mentén elterjedt továbbá a szintén őshonos Atriplex tatarica, Festuca pseudovina, Matricaria recutita. A folyamatban hirtelen változás következett be az utóbbi 10 évben, eddig nem regisztrált honos fajok tűntek fel az útpadkákon [pl. Plantago maritima (BARINA 2007), Limonium gmelinii (BAUER 2015, SCHMOTZER 2015), Podospermum canum (SCHMotZer 2015), Bupleurum tenuissimum (SCHMIDT et al. 2016), Taraxacum bessarabicum (KIRÁLY \& KIRÁLY 2018)]. Az ökológiai folyosók nemzetközi összekapcsolódásának eredményeként hazánkban nem honos sótűrő fajok is megjelentek. Néhány év alatt futótűzszerúen elterjedt a Plantago coronopus (SCHмIDT et al. 2016), hasonló karakterrel rendelkezik az először 2016-ban felbukkant Cochlearia danica (FEKETE et al. 2018) is. A határon átívelő gyorsforgalmi úthálózat kiépülése eredményezte a Dittrichia graveolens (SCHMIDT in TAKÁCS et al. 2013), a Sporobolus vaginiflorus (KIRÁLY \& HOHLA 2015), és az Atriplex micrantha (KirÁLY \& HoHLA in MEsterházy et al. 2017) feltűnését is az elmúlt években.

\section{Irodalmi áttekintés}

Az egy-kétéves életformájú sziki budavirág [Spergularia marina (L.) Bess., gyakran használt szinonímja: $S$. salina J. et C. Presl] csaknem valamennyi földrészen előforduló sótűrő növény (Soó 1970, HULTÉN \& FRIES 1986). Természetes areájának pontos határai ugyanakkor nem tisztázottak (KAPLAN et al. 2016). Európa nagy részén előfordul, a tengerpartokon a parti zóna sós mocsaraiban, a szárazföld belsejében a természetes szikeseken található. Hazánkban a kontinentális szikes növényzet egyik jellegzetes képviselője, vakszikes és szikes tófenék- és iszaptársulások társulásalkotó eleme (BORHIDI 2003). ANONYMus (2009) szerint az Alföld területén szórványos, a Kisalföldön ritka, a hegységperemen és a Balaton-parton igen ritka. A Flóraatlaszban (BARTHA et al. 2015) mindössze 23 flóratérképezési egységből jelenik meg adata, ami a hazai szikes társulások elterjedésének ismeretében egyes területeken (pl. Duna-Tisza köze) jelentős alultérképezettséget sugall. Ennek hátterében a növény apró termete, jelentéktelen külseje állhat. A faj számára kedvező természetes szikesek a Dunántúl területén a Mezőföldön, a Fertő- és a Velencei-tó, valamint a Balaton mellékén, továbbá Győr környékén vannak, ezek közül azonban csak a Mezőföldről és Győr mellől vannak régi megfigyelései [vö. KovÁTS \& SzUJKó-LACZA (1979) térképét]. Napjainkban mezőföldi adatai megerősítetlenek, a Kisalföld keleti részéről egy-egy adatot közöl SCHMIDT (2007) és RIEzING (2012) iszapos parlagról. A faj nómenklatúráját KIRSCHNER et al. (2007) tisztázta, eszerint a Magyarországon általánosan használt S. salina (pl. KIRÁLY 2007, ANONYMUS 2009) előtt prioritást élvez a $S$. marina név, ezért munkánkban is ezt a nevet használjuk.

A szárnyasmagvú budavirág [Spergularia media (L.) C. Presl, gyakran használt szinonímja: S. maritima (All.) Chiov.] rövid életű évelő faj. Elterjedésének súlypontja Eurázsia nyugati részének tengerparti sávjában és a szárazföld belsejének szikes területein található (FRIEDRICH 1979), ezen kívül Észak- és Dél-Amerika, Kelet-Ázsia és Ausztrália területén behurcolt fajként tartják nyilván (Soó 1970, HARTMAN \& RABELER 2005). Hazánkban az Alföld szikes területein szórványos, másutt ritka, ANONYMus (2009) szerint az Alföldön kívül adventív elem. Őshonos elterjedési területén a szukkulens sziki vegetáció tagja, hazánkban a sósagyagos talajú szikes tófenéken kialakuló növényzet egyik jellegzetes, társulásalkotó növény- 
faja (BoRHIDI 2003). Megjelenik továbbá alföldi legelők pata- és keréknyomaiban, iszaptársulásokban. Hazai előfordulási körzete sziki társulásaink elterjedésével mutat átfedést, adatai így főként a Duna-Tisza köze, a Hortobágy, valamint a Mezőföld és a Fertő-tó szikeseiről származnak, ez rajzolódik ki KovÁTS \& SzUjKó-LACZA (1979) térképén is. Általánosnak gondolt alföldi gyakorisága ellenére viszonylag kevés publikáció említi tételesen és jól lokalizálhatóan, ennek következtében a Flóraatlasz (BARTHA et al. 2015) mindössze 36 flóratérképezési kvadrátból ábrázolja, különösen a Dunától keletre jelenik meg kevés (17) adat.

\section{Határozási nehézségek}

A hazánkból ismert három őshonos budavirág faj (Spergularia marina, S. media, S. rubra) egymástól való elkülönítése az első ránézésre meglehetősen hasonló morfológiai alaptulajdonságaik és élőhelypreferenciájuk következében nem számít a legkönnyebb feladatnak. Erről tanúskodnak az MTM Növénytárában található herbáriumi lapok revíziós cédulái, valamint a szakirodalomban előforduló téves jelzések (vö. KovÁTs \& SzUjKó-LACZA 1979). Az ANONYMUS (2009) határozókulcsa által felületesen említett, de terepi azonosításkor fontos és könnyen vizsgálható bélyeg a hártyás szárnyat viselő és a szárnyatlan magvak aránya a toktermésben. A kulcsban szereplő információkkal ellentétben a csak szárnyas szegély nélküli magvak jelenléte nem kizárólagos elkülönítő bélyeg a $S$. marina-val szemben. KúR \& DUCHÁČEK (2016) csehországi vizsgálatai alapján a szárnyas szegéllyel rendelkező magvak aránya a toktermésben a $S$. marina-nál 0-18(-58)\%, a $S$. rubra esetében mindig 0\%. Megfigyeléseink szerint a $S$. marina útpadkákon növő állományaiban a toktermésekben sok esetben egyáltalán nincsenek szárnyas szegéllyel rendelkező magvak (ritkán előfordul 1-1 szárnyas mag), ami a hazai kulcsot (ANONYMUS l.c.) használva téves határozást eredményezhet. Kétséget kizáró faji azonosítás a magvak tulajdonságai mellett a szár- és pálhalevelek, valamint a növény szőrözöttségének vizsgálata alapján lehetséges. Megjegyzendő, hogy a $S$. rubra előfordulását eddig nem tapasztaltuk a vizsgálatba vont autóutak mellett. [SCHMIDT et al. (2016) cönológiai tabellájában szereplő adata téves, lásd alább.] A Spergularia nemzetség határozókulcsának (ANONYMUS 2009) módosítását KÚR \& DUCHÁČEK (2016) morfometriai adatai és saját megfigyeléseink felhasználásával az alábbiakban közöljük.

$1 a$ A virág 8-12 mm Ø. A tok (5-)6-8(-10) mm hosszú, kb. 2× hosszabb a csészénél. A magok világosbarnák, (75-)96-100\%-uk széles hártyás szegélyű. - A levél húsos, csúcsa nem szálkás. A szirom 2,5-5 mm hosszú, halvány rózsaszínű, töve fehér. Porzó (7-)10. T: 5$20(-40)$ cm. He. VII-X. Agyagos-szikes pionír társulások, az utak sózásával terjed. DDt (Balaton-part) ritka, NA szikes területein szórv., KisA ritka, másutt (pl. NyDt) adv. [S. maritima (All.) Chiov.]

S. media (L.) C. Presl - Szárnyasmagvú budavirág

1b A virág 6-8 mm $\emptyset$. A tok 2,5-6 mm hosszú, alig hosszabb a csészénél. A magvak nagy része v. az összes mag hártyás szegély nélküli ........................................................................... 2

2a A növény élénkzöld. A levelek húsosak, csúcsuk nem szálkás, t-k kopasz. A magok világosbarnák, széles hártyás szegély nélküliek v. kisebb részük hártyás szegélyű. A pálhák egy része a tövénél összenőtt, 1-2× olyan hosszúak mint szélesek, alig fényesek, csúcsuk tompa. A szirom 2-3 mm hosszú, sötét rózsaszínű, töve élesen elválva fehér. Porzó (2-)5(-9). A tok kevéssel hosszabb, mint a csésze. T: 5-20 cm. Th-HT. V-X. Agyagos-szikes pionír társulások, az utak sózásával terjedőben. K (szélei), DDt (Balaton-part), KisA ritka, NA szikes területein szórv., másutt (főként Dt) adv. [S. salina J. et C. Presl]

S. marina (L.) Bess. - Sziki budavirág 
2b A növény mirigyszőröktől szürkészöld. A levelek nem húsosak, csúcsuk szálkás, ált. dúsan mirigyszőrös. A magok sötétbarnák, széles hártyás szegély nélküliek. A pálhák szabadok, 2-3× olyan hosszúak mint szélesek, fényesek, csúcsuk kihegyezett. A szirom 1,5-4 mm hosszú, élénk rózsaszínű, töve alig halványabb. Porzó 5-10. A tok olyan hosszú, mint a csésze. T: 5-30 cm. Th-HT. V-IX. Mészkerülő. Szántók, nedves gyomtársulások, iszaptársulások. M.e.t. szórv.

S. rubra (L.) J. et C. Presl - Piros budavirág

\section{Másodlagos terjedés}

A cikkünkben tárgyalt két budavirág faj antropogén környezetben fellépő terjedése a 2010es évekig jószerivel ismeretlen volt hazánkban. A sziki budavirág (Spergularia marina) természetes élőhelyein kívüli, másodlagos terjedésére Ausztriában már az 1970-es évektől felfigyeltek (FRIEDRICH 1979). Régóta ismert Csehországból (СHocholoušKová 2013), ahol ma már az egész országban előfordul utak mentén (KAPLAN et al. 2016), innen tovább terjedve megjelent a szlovákiai autópályák mentén is (GoliAšová 2012, DíTĚ \& DíTĚTovÁ 2016). Az említett országok területén kelet-délkelet felé jól követhető terjedése ismeretében nem volt váratlan hazai felbukkanása. Határozóink egészen a közelmúltig nem jelzik adventív előfordulását, elsőként KiRÁLY et al. (2015) konkrét lelőhely nélkül említi, mint autópálya mellett terjedő sótűrő fajt, egy későbbi cikkben már konkrét adatokat is felsorol az M7-es autópálya Balatontól délnyugatra eső szakaszáról (KIRÁLY \& KIRÁLY 2018). Sajnálatos félrehatározás folytán SchmidT et al. (2016) Szombathelyen készített cönológiai felvételében (p. 333.) Spergularia rubra-ként szereplő növény valójában szintén $S$. marina volt. Ez alapján a növény útpadkákhoz kötődő terjedésének megindulása a 2010-es évek kezdetére tehető.

A szárnyasmagvú budavirág (Spergularia media) terjedése kevésbé számít újkeletű megfigyelésnek Európában és hazánkban (lásd ANONYMus 2009 megjegyzését). Közép-Európában elsőként HoHLA \& MELzER (2003) számol be út menti megjelenéséről Alsó-Ausztriából, Csehországban 2008-tól KúR \& ŠTECH (in KoCIÁN 2015) nyomán ismert hasonló élőhelyekről. KociấN (l.c.) személyes közlésre hivatkozva említi magyarországi és szlovákiai terjedését is. A S. marina-val szemben megfigyelhető lassabb térhódításának hátterében ScoTT \& DAVISON (1982) északkelet-angliai tapasztalatai szerint a növény nagyobb tömegű magjai, az eltérő életforma, valamint az élőhelypreferencia áll. Első konkrét hazai adata egy autópálya (M1, Győrújbarát) mellett készített cönológiai felvételben jelenik meg (SCHмIDT et al. 2016).

\section{Anyag és módszer}

Munkánk során egyszerű jelenlét-hiány módszer alapján vizsgáltunk meghatározott útszakaszokat. A helyszíneket a célnak tekintett élőhelyek speciális feltételeihez igazítva jelöltük ki. Gyorsforgalmi autóutak (autópályák, autóutak) mellett pihenőhelyeken és lehajtóknál, főutak és alsóbbrendű utak mentén elsősorban kereszteződések, körforgalmi csomópontok, leállósávok mellett végeztünk adatgyüjtést. Nem zárt pályás autóutak mentén megfelelő élőhely- és fajismeret birtokában összefüggő budavirág-populációk nemzetség szintű felismerése akár mozgó személygépkocsiból sem volt nehéz feladat, kisebb populációk megtalálása ugyanakkor csak célzott kereséssel volt lehetséges. Erre a legalkalmasabb és leghatékonyabb módszernek a kerékpáros adatgyüjtés bizonyult, amellyel hosszú szakaszokon hasonló részletességgel végeztük az útpadka növényzetének florisztikai vizsgálatát. 
A vizsgálatba vont útszakaszok (autópályák, autóutak, főutak) hosszúsága összesen 826 km volt. Célzott adatgyűjtések a következő autóút szakaszok mellett történtek (zárójelben a vizsgált szakaszok és hosszuk):

1. Autópályák: M1 (Budapest - Mosonmagyaróvár, 150 km), M7 (Budapest - Székesfehérvár, $40 \mathrm{~km}$ )

2. Gyorsforgalmi autóutak: M19 (Győr - Győrszentiván, 10 km), M85 (Csorna - Szombathely, $67 \mathrm{~km}$ )

3. Főutak: 1-es út (Győr, Tatabánya, pontszerü mintavétel), 8-as út (Szentgotthárd Veszprém, $140 \mathrm{~km}$ ), 74-es út (Vasvár - Zalaegerszeg, $23 \mathrm{~km}$ ), 76-os út (Zalacsány Keszthely, 13 km), 81-es út (Győr, Kisbér, pontszerű mintavétel), 83-as út (Győr, Pápa, pontszerű mintavétel), 84-es út (Jánosháza - Sopron, $80 \mathrm{~km}$ ), 85-ös út (Győr - Sopron, $80 \mathrm{~km}$ ), 86-os út (Mosonmagyaróvár - Zalalövő, 150 km), 87-es út (Kőszeg - Kám, 50 km), 88-as út (Vát - Sárvár, 12 km), 89-es út (Szombathely - Bucsu, 11 km).

\section{Eredmények}

A Spergularia marina összefüggő gyepet képező, monodomináns szőnyegét figyeltük meg az M1-es autópálya és a 86-os főút egyes szakaszain. Ilyen jellegű állományai rendszerint az aszfaltcsíkkal közvetlenül érintkező, a legszélsőségesebb talajadottságú (10-30 cm szélességű) sávot uralják. 2013 és 2018 között összesen 14 északnyugat-dunántúli főközlekedési út mellől mutattuk ki a faj kisebb-nagyobb állományait (1. ábra). Az eltérő terjedési stratégiával rendelkező Spergularia media útmenti populációi az M1-es és M7-es autópályák mellől, a 8687-es út szombathelyi elkerülő szakaszáról, valamint a 74-es úton Vasvár belterületén kerültek elő (2. ábra).

\section{Adatok felsorolása}

Adatainkat az autóutak jelzése alapján rendeztük sorba. A településhatár megadása után zárójelben a pontos lokalitás (ha megadható), a gyűjtés évszáma, valamint a KEF-azonosító szerepel. Több, azonos településhatárba eső lokalitást pontosvessző választ el egymástól.

\section{A Spergularia marina útmenti előfordulásai}

M1: Lébény (Lébényi lehajtó D, 2016, 8370.1), Győr (Soproni lehajtó D, 2013, 8371.1; Arrabona pihenő D, 2017, 8371.4 és 8372.3; Győrszentiváni lehajtó, 2017, 8372.2), Nagyszentjános (Bőnyi lehajtó É, 2018, 8373.1), Mocsa (Lacházy pihenő D, 2017, 8374.2), Tata (Grédics pihenőhely D, 2017, 8375.3; Tata-Környe lehajtó D, 2017, 8375.4; Remeteségi pihenőhely D, 2017, 8376.3), Tatabánya (Tatabánya-Centrum lehajtó D, 2017, 8476.1), Óbarok (Óbarok pihenőhely D, 2017, 8477.3), Zsámbék (Zsámbéki pihenőhely D, 2017, 8478.3),

M19: Bőny és Győr (M1-es csomópont, 2013, 8372.2).

M86: Szeleste és Ölbő (Szelestei lehajtó É, 2018, 8667.3).

8: Duka (buszmegálló, 2017, 8868.4), Hosszúpereszteg (2017, 8867.4), Csipkerek (2017, 8867.4), Alsóújlak (2017, 8966.2), Vasvár (Mol-kút, 2017, 8966.2), Rábahídvég (2018, 8966.2), Körmend-Horvátnádalja (Pinka-híd közelében, 2018, 8965.3), Csákánydoroszló (vasútállomás és a benzinkút között, 2018, 9064.2 és 9065.1), Rátót (2018, 9064.2), Rönök (2018, 9064.1), Szentgotthárd (rábafüzesi letérő, 2018, 9063.2; határátkelő, 2018, 9063.2). 74: Vasvár (győrvári elágazás, 2018, 8966.4), Egervár (2018, 9067.3), Zalaegerszeg (Egervári út, 2018, 9167.1). 
84: Jánosháza (8-as út körforgalmi csomópont, 2017, 8868.4), Gérce (Gércei elágazás, 2018, 8767.4), Sárvár (834. út körforgalmi csomópont, 2015, 8767.4; 88-as út csomópont, 2017, 8767.2).

85: Veszkény (vasúti megállóhely melletti szakasz, 2017, 8468.2), Kapuvár (2017, 8468.1), Fertőendréd (agyagosszergényi elágazás, 2017, 8467.2; pihenőhely a Fácános-erdőtől Ny-ra, 2017, 8467.2), Nagycenk (84-es út csomópont, 2017, 8366.3).

86: Szőce (régi Zalaháshágyi vasútállomás mellett, 2015, 9065.4), Nádasd D (2016, 9065.2), Egyházasrádóc (a település déli részén, 2015, 8965.2), Szombathely (Újperint és Petőfitelep között, 2017, 8865.2; szombathelyi elkerülő déli és keleti részén végig, 2015, 8765.4; Zanat (autópálya-felüljáró, 2015, 8766.1), Vassurány (2015, 8766.1), Nemesbőd (2015, 8766.1), Vát (88-as út csomópont, 2015, 8766.2), Pósfa (2017, 8667.3), Hegyfalu (2017, 8667.1), Vasegerszeg (tömeges, 2017, 8667.2), Vámoscsalád (tömeges, 2017, 8667.2 és 8567.4), Répcelak (2017, 8568.3), Szilsárkány (M86 körforgalmi csomópont, 2018, 8469.1).

87: Kőszeg (határállomástól a vasútállomásig, 2018, 8565.3 és 8665.1), Gyöngyösfalu (vasúti átjárótól 1300 méterre délre tömeges, 2018, 8665.4), Gencsapáti (2018, 8665.4 és 8765.2), Szombathely (Stromfeld lakótelep melletti szakasz, 2015, 8765.2; Söptei úti körforgalmi csomópont, 2017, 8765.2; Szervizi úti csomópont, 2015, 8765.4; Szentkirály melletti szakasz, 2015, 8766.3), Táplánszentkereszt (Szentkereszt, 2018, 8866.1).

86-87: Szombathely (a közös útszakasz egészén előfordul, sokfelé tömeges, 2015, 8765.4). 88: Sárvár (északi részén végig, 2015, 8767.2 és 8767.1), Ölbő (vasúti átjáró, 2017, 8767.1). 89: Szombathely (ÉNy-i elkerülő, 2015, 8765.1).

861: Kópháza (84-es úti körforgalom, 2018, 8365.4; vasúti felüljáró, 2017, 8365.4).

További másodlagos, de főútvonalakat elhagyó útszéli megtelepedése ismert Szombathelyen a Csaba út szegélyén $(2018,8765.4)$, valamint a Dolgozók útja és a Muskátli út mentén (2016, 8765.4). Megjelenésükkel kapcsolatban mindegyik lelőhelyen egyértelmű összefüggés állapítható meg a közelben haladó fóutak (86-87. illetve 89.) menti gazdag populációkkal.

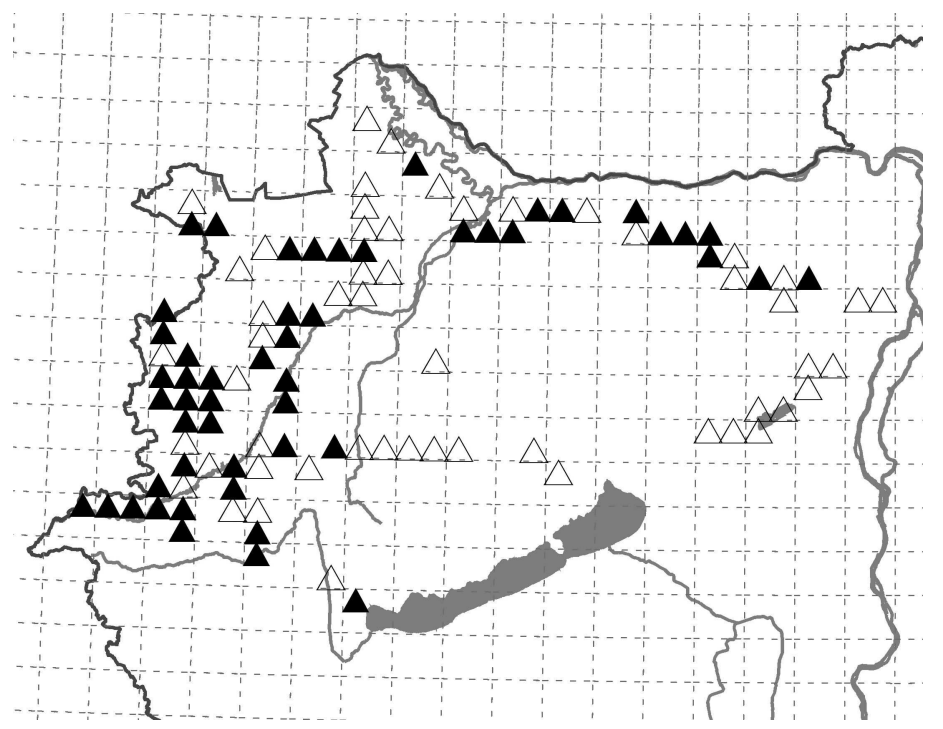

1. ábra. A Spergularia marina útmenti előfordulásai a Dunántúlon

Fig. 1. Occurrences of Spergularia marina along roadsides in Transdanubia (Hungary) Јelmagyarázat: teli háromszög: vizsgált útszakasz S. marina előfordulásával; üres háromszög: vizsgált útszakasz $S$. marina előfordulása nélkül

Legend: full triangle: investigated road sector with occurrence of $S$. marina; empty triangle: investigated road sector without occurrence of $S$. marina 


\section{A Spergularia media útmenti előfordulásai}

M1: Győr (Arrabona pihenőhely D, 2013, 8371.4; Soproni lehajtó D, 2013, 8371.1; Győrszentiváni lehajtó D, 2013, 8372.2), Nagyszentjános (Bőnyi lehajtó D, 2013, 8373.1), Ács (Concó pihenőhely D, 2013, 8373.2), Tata (Grédics pihenőhely D, 2017, 8375.3), Tatabánya Bicske (Nagyegyháza-Bicske lehajtó D, 2017, 8477.4).

M7: Pákozd (Pákozdi pihenőhely, 2017, 8777.3), Székesfehérvár (Székesfehérvár-Kelet lehajtó, 2017, 8877.1; Fehérvári pihenőhely, 2017, 8876.2).

1: Tatabánya (M1 Tatabánya-Óváros lehajtó körforgalmi csomópont, 2016, 8476.2).

74: Vasvár (Győrvári út, 2018, 8966.4).

86: Szombathely (szombathelyi elkerülő keleti része a vépi úti körforgalom közelében, néhány tő, 2017, 8765.4).

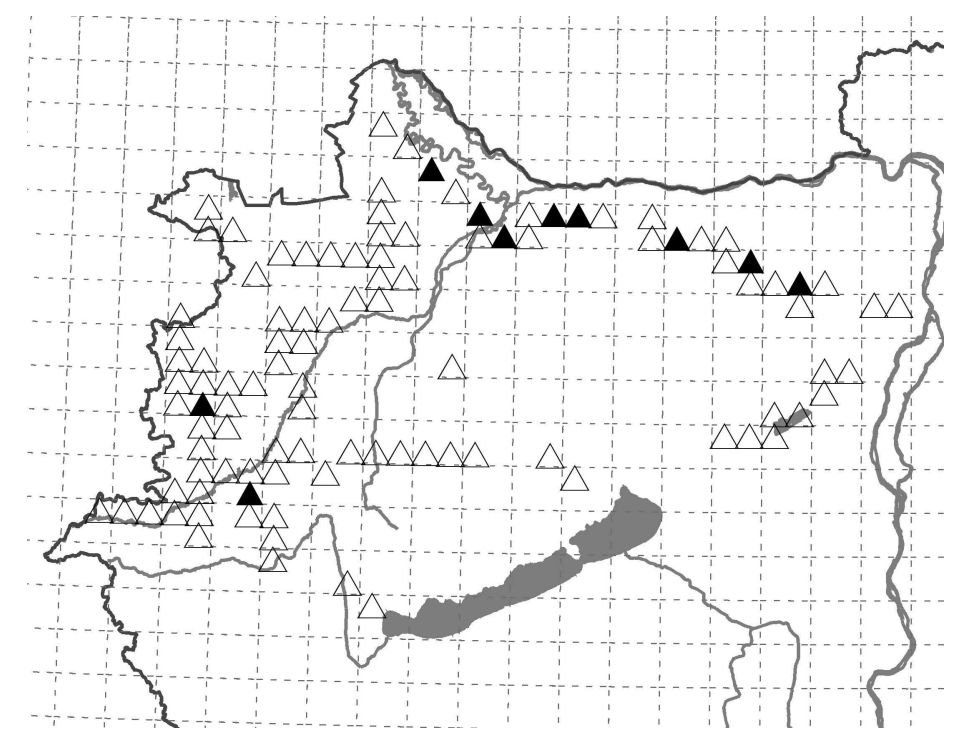

2. ábra. A Spergularia media útmenti előfordulásai a Dunántúlon

Fig. 2. Occurrences of Spergularia media along roadsides in Transdanubia (Hungary)

Jelmagyarázat: teli háromszög: vizsgált útszakasz Spergularia media előfordulásával; üres háromszög: vizsgált útszakasz Spergularia media előfordulása nélkül

Legend: full triangle: investigated road sector with occurrence of Spergularia media; empty triangle: investigated road sector without occurrence of Spergularia media

\section{Megvitatás}

A sótűrő Spergularia-fajok alig egy-két évtizede kezdtek terjedni Közép-Európa útjain, amelynek hátterében az aszfaltburkolatú utakon Európa-szerte, így hazánkban is alkalmazott téli sózási tevékenység áll. A járműforgalom és a csapadék által az útpadkák felé áramló sós hólé beszivárogva a talajba jelentős változást okoz a rajta megtelepedő növényzetben. Eredményeképpen egy keskeny, elszikesedett sáv jelenik meg az aszfaltcsíkkal párhuzamosan, ami alkalmas életteret kínál az erős mechanikai és ozmotikus stresszt elviselő halofitonoknak (SCOTT \& DAVISON 1985, PERKINS 2003). Mindkét, cikkünkben tárgyalt Spergulariafaj elviseli a szélsőségesen szikes (vakszik jellegű) talajokat, valamint az erősen taposott felszíneket, így sikerrel képes meghódítani a sózás hatására elszikesedett útpadkákat. Terjedésüket ugyancsak elősegíti gyenge kompetíciós képességük, ami miatt más élőhelyeken nem versenyképesek, sós környezetben azonban sikeresek (BARBOUR 1978). Országonként és 
régiónként változó a kijuttatott só mennyisége, csehországi megfigyelések szerint nagyobb mennyiségú sót elsősorban a hegyvidéki területeken juttatnak ki, emiatt magasabb a Spergularia marina borításértéke (KAPLAN et al. 2016). Hasonló összefüggést a vizsgált útszakaszokon nem mutattunk ki, szőnyegszerű állományok teljesen sík autópálya-szakaszokon (pl. M1 Győrnél, $115 \mathrm{~m}$ tszf.) éppúgy jelen vannak, mint dombvidéki területeken (pl. 8-as út: Szemenye és Hosszúpereszteg között, 235 m tszf.; 87-es út: Kőszeg, 290 m tszf.). Ide kívánkozik ugyanakkor egy megfigyelés a Kőszegi-hegység ausztriai oldaláról, ahol a hegységen átvezető fóút legmagasabban fekvő szakasza mentén ( $800 \mathrm{~m}$ tszf.) is magas egyedszámban van jelen a növény (Schmidt D. ined.). Itt bizonyára a téliesebb útviszonyok miatt nagyobb mennyiségú sót juttatnak ki az útra.

Arra a kérdésre, hogy miért csak a legutóbbi időkben indult meg a két faj (helyenként tömeges) utak menti terjedése, a közlekedési háttértényezők változásának ökoszisztémára gyakorolt hatásában keresendő a válasz. A belföldi gyorsforgalmi úthálózat technikai fejlesztése a 2010-es évektől a korábbinál is intenzívebbé vált, és a 2010-es évekre az egységes nemzetközi hálózathoz való kapcsolódást eredményezte (SCHMIDT \& KIRÁLY 2016). Az esetenként több száz kilométeren át összefüggővé vált és szerkezetét tekintve zárt élőhelyfolyosók a nemzetközi útépítési szabályrendszer miatt igen hasonló feltételeket kínálnak, amely megnöveli a tág ökológiai tűréssel rendelkező fajok potenciális életterét (GRIESE 1998). Terjedésüket kedvezően befolyásolja az Európa-szerte lényegesen megnövekedett gépjárműforgalom. Magyarországon az országos forgalomszámlálásba vont utakon 2012-2017 között az összes forgalmi teljesítmény 19,7\%-kal növekedett, ezen belül a személygépkocsi forgalom 23,9\%-kal, a tehergépkocsi forgalom 7,1\%-kal nőtt [1]. Az általunk vizsgált utakon különösen a nemzetközi fuvarozást bonyolító nehézgépjárművek (kamionok) száma nőtt meg, a 86-os és 87-es főutak szombathelyi elkerülő szakaszán például 5 év alatt 48\%-kal nőtt a tehergépjármüforgalom [1]. Egyes útszakaszokon, (pl. M1, 8-as főút, 86-os főút) szinte állandó turbulenciát keltenek az elhaladó gépjárművek, ami lehetővé teszi egyes fajok igen gyors és hatékony terjedését (SCHMIDT 1989, GRIESE 1998). Terjedésükkel egyidejúleg az új állományok kialakulásának és fennmaradásának gyakran gátat szab a rendszeresen elvégzett útkarbantartási munka. Az útburkolat felújítása és javítása a legtöbb esetben együtt jár az útpadkákon addig kialakult növényzet megsemmisülésével, az elegyengetett útszegélyre frissen szórt védőanyag (murva, kőzúzalék, ritkábban föld) két-három évig növényzetmentes marad, csak lassan hódítják meg újra a növények. A 8-as úton Alsóújlak és Szemenye, illetve a 86-os úton Egyházasrádóc és Balogunyom közötti szakaszán az utóbbi években végzett útfelújítás eltüntette a kialakult sótűrő vegetációs sávot. Megfigyeléseink szerint megfelelő terjedési feltételek és elegendő mennyiségű propagulumforrás mellett a Spergularia marina-nak elegendő 2 év, hogy egy felújított útszakaszt tömegesen kezdjen meghódítani. A forgalomnak 2016-ban átadott M86-os autóút mentén a szelestei lehajtónál 2018-ra már gazdag állományai jelentek meg. A Spergularia media hazai terjedési intenzitásával kapcsolatos tapasztalataink megerősítik SCOTT \& DAVISON (1982) és KAPLAN et al. (2016) megfigyeléseit. Útmenti lelőhelyei és populációnkénti egyedszáma általában jóval csekélyebb, mint a $S$. marina esetében, amelynek hátterében eltérő életformája és magjainak nagyobb tömege állhat (KúR \& DUCHÁCEK 2016). Összefüggő, szőnyegszerű állományok igen ritkán fordulnak elő, pl. az M1-es (Grédics pihenő, Győrszentiváni lehajtó) és az M7-es (Fehérvári pihenő) autópályák útpadkáin. Ezen előfordulások túlnyomó része földrajzilag igen közel esik olyan természetközeli szikes élőhelyekhez, ahol a faj egykor előfordult vagy ma is él. Az M7-es autópálya mentén, a Velencei-tó környékén, az M1-es autópálya mentén Győr térségében figyeltük meg állományait. Az M7-es autópálya Pákozdi pihenőhelyén és a Székesfehérvár-Kelet lehajtó környékén az útpadka természetes szikes gyeptársulásokkal érintkezik, ezért nem meglepő, hogy itt több sziki faj is megjelenik (pl. Aster pannonicus, Limonium gmelinii, Matricaria recutita, Plantago maritima). Győr és Tata környékén azonban az egykori szikeseknek már csak romjai maradtak (vö. 
SCHMidT 2007), ezért valószínűtlennek látszik, hogy szerepet játszanak a faj jelenkori terjedésében. Ezen populációk valódi eredetét molekuláris genetikai vizsgálatokkal lehetne bizonyítani. Minden kétséget kizáróan a gépjárműforgalom játszotta a szerepet a Szombathely melletti felbukkanásában, a lelőhely ugyanis igen jelentős távolságra (>100 km) van a faj legközelebbi potenciális élőhelyétől.

Természetvédelmi szempontból érdekes kérdés a két faj helyzete. Az eredeti termőhelyeiken előforduló populációk nagysága egyik faj esetében sem számottevő, élőhelyük sérülékeny, megjelenésük gyakran időszakos. Sérülékenységük bizonyítékaként a Spergularia marina a Vörös Listán is szerepel (KIRÁLY 2007). Ezzel szemben útpadkákon gyakran rendkívül magas példányszámban lépnek fel, sok esetben összefüggő növényzeti sávot képeznek. Ezek a populációk példányszámban jelentősen meghaladják a természetes szikeseken élő állományokét, ennek ellenére nem gondoljuk, hogy természetvédelmi szempontból, mint kímélendő értékekre túl nagy hangsúlyt kell fektetni. Magát a szikesedést előidéző téli útsózás és mechanikai igénybevétel is erős antropogén hatásnak számít, amelynek közvetlen hatására a tájban idegen módon jelennek meg állományaik. Ráadásul az útkarbantartási munkák közül a kaszálás kifejezetten előnyös számukra, hiszen mindkét faj elterülő, nem felemelkedő hajtással rendelkezik, így az alacsony vágási magasságban végzett kaszálás nem károsítja az egyedeket, sőt, terjedésüket segíti. A szintén elterjedt herbicides gyomirtás hatására ugyanakkor az útszegély teljes növényzete elpusztul, emellett súlyos környezeti ártalmakkal jár, alkalmazását ezért korlátozni kell.

\section{Köszönetnyilvánítás}

Köszönjük a cikk két lektorának javaslataikat és az építő jellegü kritikát.

\section{Irodalomjegyzék}

ANonYmus (2009): Szegfüfélék családja. Caryophyllaceae. - In: KIRÁLY G. (szerk.), Új magyar füvészkönyv. Magyarország hajtásos növényei. Határozókulcsok. Aggteleki Nemzeti Park Igazgatóság, Jósvafö, pp. 132-149.

BARBour M.G. (1978): The effect of competition and salinity on the growth of a salt marsh plant species. - Oecologia 37: 93-99.

BARINA Z. (2007): A Vértes és környéke florisztikai kutatásának eredményei I. - Kitaibelia 12: 30-40.

Bartha D., Király G., Schmidt D., Tiborcz V., Barina Z., CSiKy J., JakAB G., LeSKu B., SchmotZer A., VidéKi R., Vojткó A. \& Zólyomi Sz. (szerk.) (2015): Magyarország edényes növényfajainak elterjedési atlasza. Nyugat-magyarországi Egyetem Kiadó, Sopron.

BAuER N. (2015): A Limonium gmelinii (Willd.) Kuntze subsp. hungaricum (Klokov) Soó alkalmi megjelenései útpadkákon. - Kitaibelia 20 (2): 300.

BoRHIDI A. \& SÁNTA A. (2007): Vörös könyv Magyarország növénytársulásairól. I-II. - Természetbúvár Alapítvány Kiadó, 711 pp.

СносноцоUŠKovÁ Z. (2013): Výskyt Spergularia salina podél komunikací udržovaných v zimě solením. Calluna, západočeských botaniků 18: 10.

DíTĚ D. \& DíTĚTovÁ Z. (2016): Halophytes spreading along roadsides of northern Slovakia - Thaiszia Journal of Botany 26 (2): 165-172.

FeKete R., Mesterházy A., VAlKó O. \& MolnÁR V. A. (2018): A hitchhiker from the beach: the spread of the maritime halophyte Cochlearia danica along salted continental roads. - Preslia 90: 23-37.

FRIEDRICH H.C. (1979): Familie Caryophyllaceae. - In: REICHINGER K.H. (szerk.), Illustrierte Flora von Mitteleuropa. Band 3. Teil 2. Verlag Paul Parey, Berlin \& Hamburg, pp. 763-1182.

Goliašová K. (2012): Spergularia (Pers.) J. Presl. et C. Presl. - In: Goliašová K. \& Michalková E. (eds) (2012), Flóra Slovenska VI/3. Veda, Bratislava, pp. 88-99.

GRIESE D. (1998): Die viatische Migration einiger neophytischer Pflanzensippen am Beispiel norddeutscher Autobahnen. - Braunschweiger Geobotanische Arbeite 5: 263-270.

HARTMAN R. \& RABElER R. (2005): Spergularia rubra (Linnaeus) J. Presl \& C. Presl. - In: Flora of North America Editorial Committee, eds. 1993+. Flora of North America North of Mexico. 12+ vols. New York and Oxford. Vol. 5, p. 19 
Hohla M. \& Melzer H. (2003): Floristisches von den Autobahnen der Bundesländer Salzburg, Oberösterreich, Niederösterreich und Burgenland. - Linzer Biologische Beiträge 35: 1307-1326.

HULTÉN E. \& FRIES M. (1986): Atlas of North European vascular plants. North of the Tropic of Cancer, vol 1. - Koetlz Scientific Books, Königstein.

Kaplan Z., Danihelka J., ŠtěPÁnková J., Ekrt L., Chrtek J. JR., Zázvorka J., Grulich V., Řepka R., Prančl J., DuChÁČEK M., KÚR P., Šumberová K. \& BRŮNA J. (2016): Distributions of vascular plants in the Czech Republic. Part 2. - Preslia 88: 229-322.

KÁRPÁTı Z. (1954): Kiegészítés Soó - Jávorka: »A magyar növényvilág kézikönyve« c. munkájához. Botanikai Közlemények 45: 71-76.

KIRÁLY G. (szerk.) (2007): Vörös Lista. A magyarországi edényes flóra veszélyeztetett fajai. [Red list of the vascular flora of Hungary]. - Saját kiadás, Sopron, 73 pp.

KIRÁLY G. \& KIRÁLY A. (2018): Adatok és kiegészítések a magyar flóra ismeretéhez III. - Botanikai Közlemények 105 (1): 27-96.

Király G. \& Hohla M. (2015): New stage of the invasion: Sporobolus vaginiflorus (Poaceae) reached Hungary. - Studia botanica hungarica 46 (2): 149-155.

KIRSCHNER J., KIRSCHNEROVÁ L. \& ŠTĚPÁNEK J. (2007): Generally accepted plant names based on material from the Czech Republic and published in 1753-1820. - Preslia 79: 323-365.

Kocián P. (2015): Novelties in the roadside flora of Moravia and Silesia (Czech Republic) - 1. Spergularia media. - Acta Musei Silesiae, Scientiae Naturales 64: 263-267.

Kováts D. \& SzujKó-Lacza J. (1979): Distribution and diversity of the Hungarian Spergularia species (Caryophyllaceae). - Studia botanica hungarica 13: 57-73.

KöLES P. (1994): Útpályák szennyeződése és a vízlefolyás környezeti hatása. - Hidrológiai Tájékoztató 1: 14-16.

KÚR P. \& DuCHÁČEK M. (2016): Rod kuřinka (Spergularia) - výzva ke sledování [Genus Spergularia - an appeal for monitoring]. - Zprávy Moravskoslezské pobočky ČBS 5: 47-54.

Mesterházy A., Matus G., Király G., Szúcs P., TöröK P., Valkó O., Pelles G., Papp V.G., Virók V., Nemcsok Z., Rigó A., Hohla M. \& Barina Z. (2017): Taxonomical and chorological notes 5 (59-68). - Studia botanica hungarica 48 (1): 263-275.

RezniceK A.A. (1980): Halophytes along a Michigan Roadside with Comments on the Occurrence of Halophytes in Michigan. - The Michigan Botanist 19: 23-30.

RIEZING N. (2012): Adatok a Győr-Tatai Kisalföld flórájához és vegetációjához. - Botanikai Közlemények 99 (1-2): 81-102.

SCHMidT W. (1989): Plant dispersal by motor cars. - Vegetatio 80: 147-152.

SchmidT D. (2007): A Győr környéki szikesek növényzete. - Flora Pannonica 5: 95-104.

SCHMidT D., DítĚTovÁ Z., HoRvÁTH A. \& SzǓcS P. (2016): Coastal newcomer on motorways: the invasion of Plantago coronopus in Hungary. - Studia botanica hungarica 47: 319-334.

SCHMIDT D. \& KiRÁLY G. (2016): A gyorsforgalmi úthálózat szerepe egyes növényfajok terjedésében. - In: BARINA Z., BuczKó K., LőKöS L., PAPP B., PIFKó D. \& SzURDOKI E. (szerk.), XI. Aktuális flóra- és vegetációkutatás a Kárpát-medencében. Előadások és poszterek összefoglalói. Magyar Természettudományi Múzeum, Budapest, pp. 108-109.

Schmotzer A. (2015): Ceratocephala testiculata (Crantz) Roth és további adatok a Bükkalja flórájához. Kitaibelia 20: 81-142.

ScotT N.E. \& DAVISON A.W. (1982): De-icing salt and the invasion of road verges by maritime plants. Watsonia 14: 41-52.

ScotT N.E. \& DAVISON A.W. (1985): The distribution and ecology of coastal species on roadsides. Vegetatio 62: 433-440.

Soó R. (1970): A magyar flóra és vegetáció rendszertani-növényföldrajzi kézikönyve IV. - Akadémiai Kiadó, Budapest, 614 pp.

Takács A., Baráth K., Csiky J., Csikyné R.É., Király G., Nagy T., Papp V., Schmidt D., Tamási B. \& Barina Z. (2016): Taxonomical and chorological notes 3 (28-37). - Studia botanica hungarica 47 (2): 345-357.

\section{Hivatkozott világháló oldalak}

[1] https://internet.kozut.hu/Lapok/forgalomszamlalas.aspx (Hozzáférés: 2018.10.20.)

Beérkezett / received: 2018. 09. 04. • Elfogadva / accepted: 2018. 10. 29. 
SCHMIDT D., HASZONITS Gy. \& KoRdA M. (2018):

Sótürő budavirágfajok terjedése a Dunántúl útjain / Spreading of native Spergularia species along roadsides of Transdanubia (NW Hungary)

Kitaibelia 23 (2): 141-150.

DOI: 10.17542/kit.23.141

\section{Elektronikus melléklet / Electronic appendix}

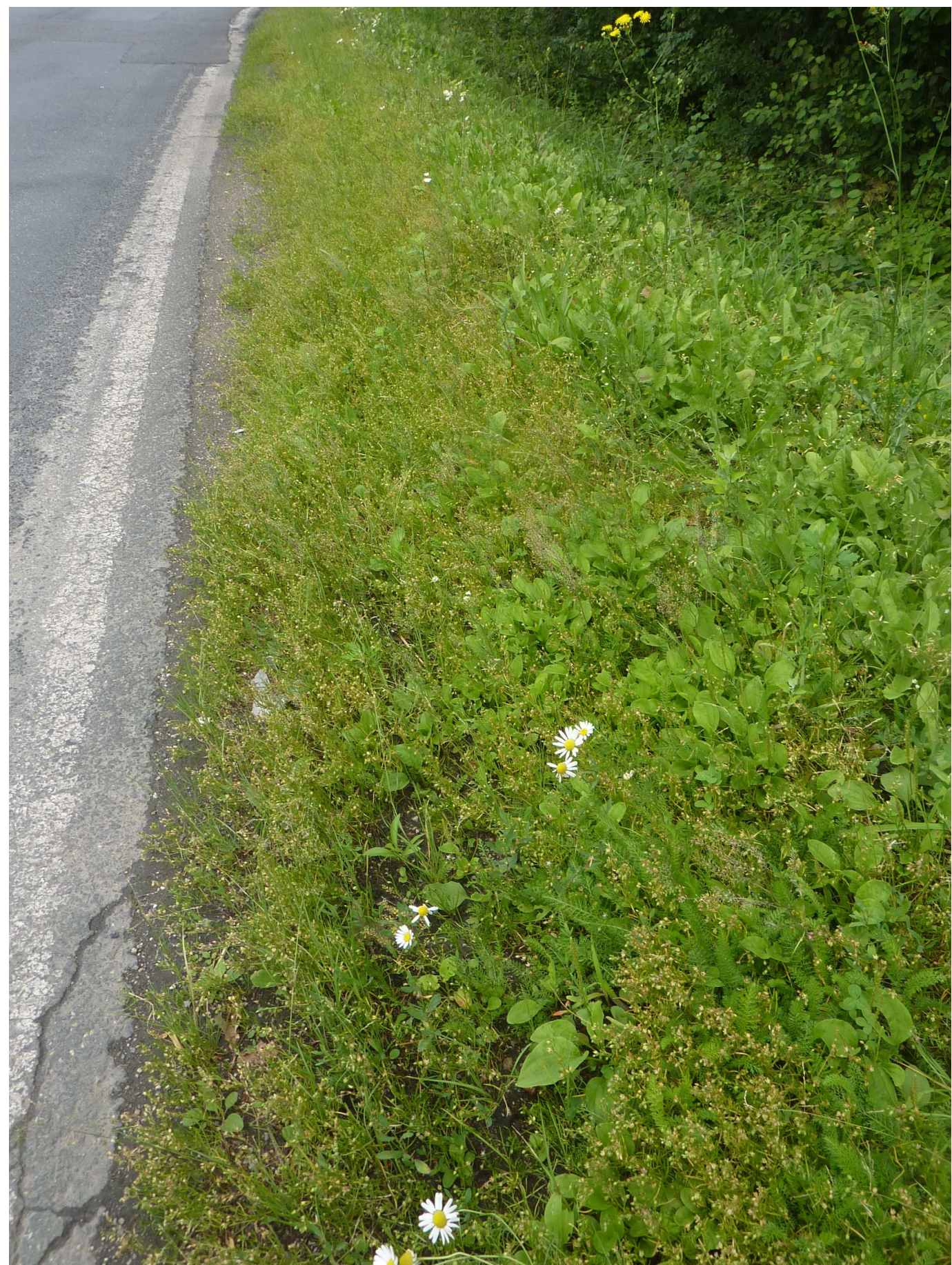

1. ábra. Spergularia marina összefüggő sávban megjelenő tömege a 87-es úton Kőszegnél (fotó: Schmidt D.) Fig. 1. Homogeneous stand of Spergularia marina along the road 87 near Kőszeg (photo: D. Schmidt, 2018) 


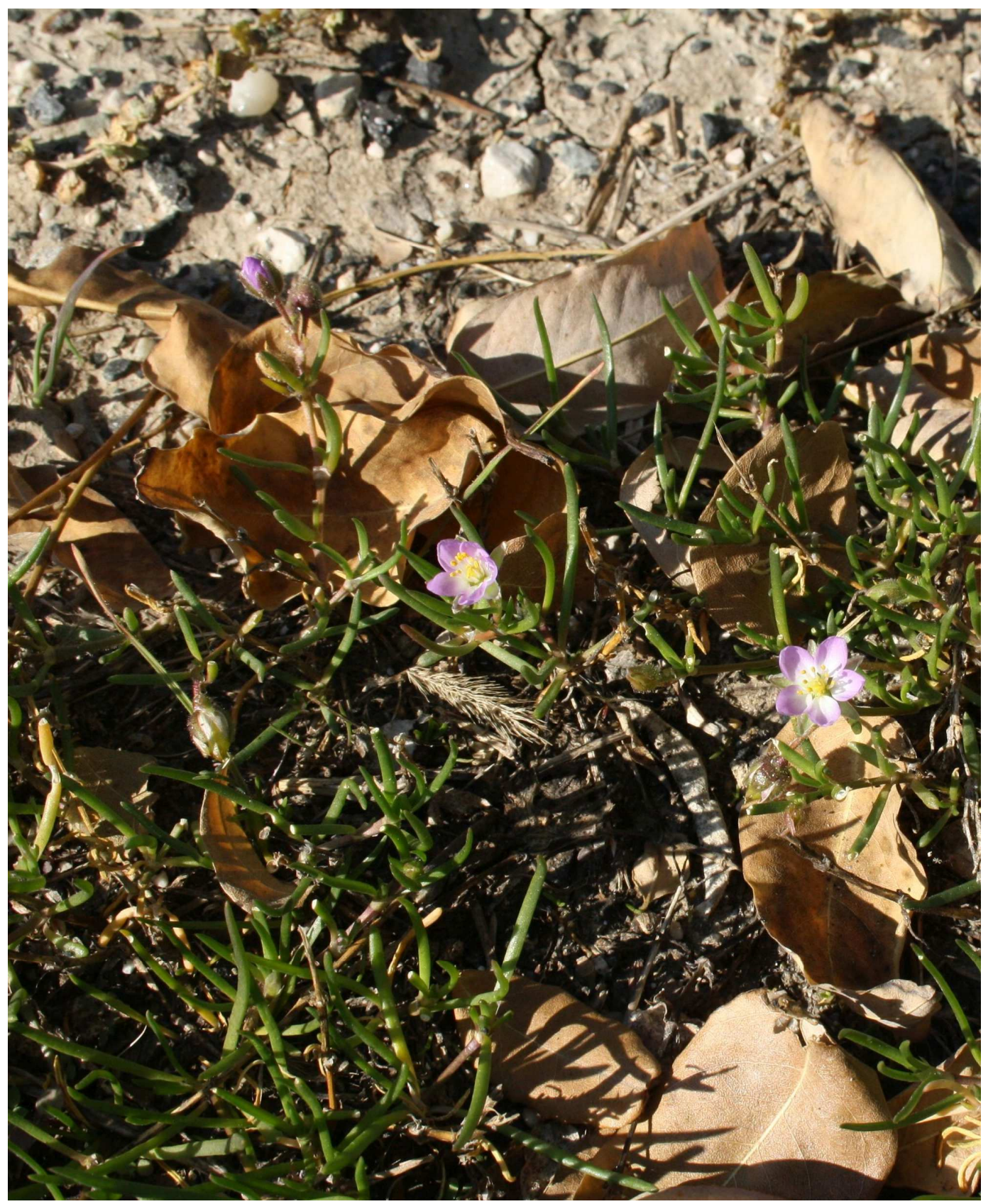

2. ábra. Elszikesedett útpadkán virágzó Spergularia media az M1-es autópályán Győr mellett (fotó: Schmidt D.) Fig. 2. Flowering Spergularia media on salty road edge along the M1 motorway near Győr (photo: D. Schmidt, 2017) 